\title{
Hegel and the Ethics of Brandom's Metaphysics
}

\author{
Jonathan Lewis
}

\section{(2) OpenEdition}

\section{Journals}

Electronic version

URL: http://journals.openedition.org/ejpap/1350

DOI: 10.4000/ejpap.1350

ISSN: 2036-4091

\section{Publisher}

Associazione Pragma

\section{Electronic reference}

Jonathan Lewis, « Hegel and the Ethics of Brandom's Metaphysics », European Journal of Pragmatism and American Philosophy [Online], X-2 I 2018, Online since 11 January 2019, connection on 19 April 2019. URL : http://journals.openedition.org/ejpap/1350 ; DOI : 10.4000/ejpap.1350

This text was automatically generated on 19 April 2019

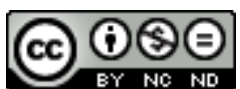

Author retains copyright and grants the European Journal of Pragmatism and American Philosophy right of first publication with the work simultaneously licensed under a Creative Commons AttributionNonCommercial-NoDerivatives 4.0 International License. 


\title{
Hegel and the Ethics of Brandom's Metaphysics
}

\author{
Jonathan Lewis
}

\section{Introduction}

1 A key theme of pragmatism during the latter half of the twentieth century has been the critique of the representationalist order of explanation. ${ }^{1}$ Although the meaning of representationalism depends on which of the philosophical sub-disciplines one chooses to engage with, common consensus (at a certain level of abstraction) is that, for representationalists, semantics comes before pragmatics, specifically, that notions such as reference and truth are explanatorily basic and can account for inference. As a result, and on the basis of a non-deflationary structure of correspondence between representations and states of affairs, those that support the representationalist order usually subscribe to the view that, for our judgments to have a truth-value, it must be possible for the properties of judgments to correspond with or refer to facts, objects or properties "out there" in the world. It is because of this relationship to the world that individuals are able to express conceptual content. For Robert Brandom, one of the figureheads of contemporary pragmatism, the representational relationship between language and the world is not an appropriate starting point for understanding meaning and truth. One of his main tasks is to show that representational ways in which concepts can have contents can be accounted for on a normative basis in accordance with the roles words play in our discursive practices. Conceptual content is determined through use thereby ensuring that meaning is (initially) expressive.

2 Ultimately, for Brandom, metaphysics is deflationary ("the world is understood in the first instance as a collection of facts, not of things; there is nothing that exists outside of the realm of the conceptual" Brandom 2000b: 357). The contents of our concepts lay claim to how the world is. Consequently, the gradual determination of conceptual content in our actual discursive practices goes hand-in-hand with the determination of facts. With the idea that "facts are true claims" - to be explained in terms "common deontic 
scorekeeping vocabulary" (Brandom 1994: 625-6) - Brandom argues that true normative claims represent normative facts in the same way as descriptive sentences. The point is that "apart from our scorekeeping attitudes of attributing and acknowledging such deontic statuses, there are no such statuses, and hence no corresponding normative facts about them" (Brandom 2000b: 365). With this move, Brandom distances himself from the dominant representationalist tradition in order to explain the sense of content bearers in terms of normative pragmatics and inferential semantics. The end result is that semantic notions such as truth and reference can be understood in terms of inferential processes of social determination and not in terms of identifications between representations and states of affairs.

3 Suffice it to say that the majority of commentators have devoted their assessments of Brandom's work to the metaphysical, semantic and perception-oriented aspects of his account of how semantic notions such as truth and reference can be understood in terms of social norms. ${ }^{2}$ The fact of the matter is, however, that Brandom draws upon, approximates and supplements key themes in German Idealism in order to explain the roles that social practice, history and tradition perform in the institution of normative statuses and the determination of concepts and facts. ${ }^{3}$ Although Brandom appropriates themes in German Idealism for predominantly metaphysical ends, these themes have an essential ethical dimension, one that has not been incorporated within his "systematic contemporary philosophical theory" nor has it been sufficiently acknowledged in his "rational reconstruction of some strands of the history of philosophy" (Brandom 2002: 15). This essential ethical dimension has also remained unexplored by the majority of those that have sought to assess Brandom's normative pragmatics and inferential semantics. ${ }^{4}$

4 For Brandom, his explanation of socially-determined facts and norms takes shape, initially, through his reading of Kant, who he sees as adopting an "innovative normative conception of intentionality" that helps us to understand the force of normative or deontic statuses like commitment, responsibility and authority ("various kinds of oughts") (Brandom 2009: 52). But Brandom's discussions concerning the self-legislation of normative statuses and one's commitments to, and responsibilities for, conceptual contents develop through a reading of Hegel and the idea that necessary normative statuses are fundamentally social statuses. Brandom supplements his reading of Kant with a reading of Hegel because he believes that normative statuses and practical attitudes (taking someone to be committed, responsible and authoritative) are the bedrock of discursive practice qua social practice. In other words, the social dimension of selflegislation and mutual-relating that Brandom sees as being supplied by Hegel is a necessary condition of the game of deontic scorekeeping, a condition that Kant is unable to provide. Brandom's framework and his appropriation of Hegel for the demands of that framework presuppose the ideal conditions of reciprocal recognitive attitudes between deontic scorekeepers. For Brandom, Hegel's notion of a "relation of reciprocity" is the basis of sociality in the sense that it provides a structure for particular acts of judgment and discursive practice in general. Furthermore, intersubjective recognitional relations that are sustained in a reciprocal way are also a necessary condition of a dynamic process that brings about the institution of normative statuses, the determination of conceptual contents and the validity of objectivity-claims.

5 What Brandom does not account for in his reading of Hegel and its assimilation to the demands of normative pragmatics and inferential semantics is the idea that the 
recognitive relationships that constitute both the structure and process of the social determination of norms and facts are, for Hegel, ethical relationships. From a Hegelian perspective, Brandom's framework faces two specific challenges. The first concerns Brandom's commitment to social positivism, whereby social practices are immune to criticism from the perspective of either an internal participant or an external observer. The second problem concerns Brandom's inability to offer a sufficient explanation for the distinction between legitimate and illegitimate norms. For Hegel, we can only make sense of such a distinction and thereby attempt to overcome the problem of social positivism by appealing to the differences between genuine responses to normative authority and illegitimate responses in real discursive situations. Such a distinction is grounded in a particular account of freedom as an achieved collective state of normative equality that licenses genuine self-determination. Accordingly, the relation of reciprocity functions as a condition for the possibility of freedom. In order to address the two challenges facing Brandom's framework, this paper proposes two Hegelian solutions. Firstly, it will be argued that, in real situations (as opposed to ideal ones), questions concerning the validity of our socially-precipitated judgments cannot be considered independently from questions regarding the legitimacy of norms in the context of the ethics of social recognition. Secondly, in order accommodate the distinction between legitimate and unjustifiable norms, a Hegelian solution challenges the notion of a unity of reason that is at the core of Brandom's normative pragmatics and inferential semantics. Such a solution appeals to the idea that ethical validity (in Hegel's sense) cannot be conflated with normative validity.

\section{Brandom's Kant: Normative Statuses, Practical Attitudes and Case Law}

6 According to Brandom, normative statuses cannot be easily distinguished; commitment, for example, places an obligation or responsibility on someone to do something whereas authority licenses someone to do the very thing that they are responsible for. For Brandom, the reason one cannot make a hard-and-fast distinction between responsibility, commitment and authority is because these normative statuses are bound up with the concept of judgment:
Spontaneity, in Kant's usage, is the capacity to deploy concepts. Deploying concepts is making judgments and endorsing practical maxims. Doing that, we have seen, is committing oneself, undertaking a distinctive sort of discursive responsibility. The positive freedom exhibited by exercises of our spontaneity is just this normative ability: the ability to commit ourselves, to become responsible. It can be thought of as a kind of authority: the authority to bind oneself by conceptual norms. That it is the authority to bind oneself means that it involves a correlative kind of responsibility [...] It is the responsibility to integrate the commitment one has undertaken with others that serve as reasons for or against it. (Brandom 2009: 59)

7 In short, according to Brandom, Kant understands judgment as committing oneself to deploying concepts and, simultaneously, taking responsibility for the concepts that one deploys as expressions of one's commitments. In other words, when it comes to "Kant's core pragmatist commitment," he "understands judging and willing as taking on distinctive kinds of responsibility. And he understands what one endorses by doing that judgeable contents and practical maxims - in terms of what one is thereby committing oneself to do, the kind of task-responsibility one is taking on" (ibid.: 52). Furthermore, 
Kant explains the conceptual contents and practical maxims that one endorses by taking on such a responsibility in terms of an authority to bind one's self to commitments and the conceptual contents of judgments that express those commitments. On the basis that our commitments stand in inferential relations to one another, this kind of authority entails a further responsibility, specifically, the responsibility to integrate commitments and their associated conceptual contents with other commitments and conceptual contents in a kind of normative spider web.

8 For Brandom (après Brandom's Kant), taking responsibility for the contents of judgment is the basis for a normative understanding of cognitive-practical activity. In judging, we are committing ourselves to deploying concepts, demonstrating our authority to bind ourselves to our objectivity-claims and undertaking responsibilities for the contents of our judgments. These statuses are, therefore, attitude-dependent. They are also normative in the sense that they can be assessed as appropriate or inappropriate, correct or incorrect. In turn, the normative content of a judgment - that which we have committed ourselves to in making a judgment and which our judgment expresses - is attitudeindependent and exercises an authority over us insofar as we adopt a practical attitude that recognises that authority. Norms, therefore, arise and are instituted within a pragmatic, inferential and contextual melting pot of both attitude-dependent and attitude-independent commitments, responsibilities, authority and acknowledgment. ${ }^{5}$

Brandom attempts to make the leap from a phenomenalist understanding of normative statuses as instituted by normative attitudes to his explanation of the entwined natures of concepts and facts by invoking a temporally perspectival model for conceptual determination. To understand the temporal dimension of conceptual objectivity and how it fits with his account of deontic scorekeeping, Brandom uses the analogy of applying and determining legal concepts in case law. ${ }^{6}$ In each new case, a judge decides whether to apply a legal concept. Each application of a legal concept to a new case helps to determine the content of that legal term. For each judgment, the judge adopts a practical attitude of recognising the authority exercised by the commitments of previous judges whose decisions have provided precedents for the application of the same legal concept. Furthermore, the judge also exercises authority over the content of the legal concepts being applied and thereby over future judges, just as past judges have exercised authority over the deciding judge through the latter's practical attitude that acknowledges their judgments. The judge thereby presents what is, in effect, a "rational reconstruction" of an authoritative tradition insofar as the tradition determines the content of a legal concept and, simultaneously, reveals what that content is and how it ought to be applied. Furthermore, the deciding judge also has a duty to future judges, for they are the ones who will adopt a practical attitude of deciding whether the commitments of the deciding judge were the "right" commitments, thereby choosing whether to acknowledge the prior judgments as authoritative.

10 According to Brandom, the result of a judge's rational integration of some new commitment via a process of rational recollection is intelligible as her commitments as to "how things really are, objectively, in themselves - as being what [she] takes to be not just an appearance of that reality, but a veridical appearance, one in which things appear as they really are" (Brandom, 2009: 100). In other words, when a judge (case-law or otherwise) takes their current commitments as the culmination of a historical process of actual rational integrations of judgments, that judge considers their commitments to be "the reality of which previous constellations of endorsements were ever more complete 
and accurate appearances" - each previous, precedential episode of rational recollection and integration is "a partial, and only partially correct revelation of things as they are now known (or at least taken) to be" (ibid.). The recollective reconstruction of a tradition of judgments, which makes reality explicit through a judge's commitments, shows how prior commitments and conceptual contents were not mere appearances; "they did genuinely reveal something of how things really are" (ibid.: 101).

\section{Is Brandom's Hegel Enough?}

Positioning his normative pragmatics and inferential semantics in relation to the work of Hegel, Brandom perceives the structure and development of his case-law analogy for the social determination of norms and facts as present in embryonic form in Hegel's practical philosophy. In a remark that seemingly summarises Brandom's stance on the subject's freedom in normatively constituted judgments, Hegel suggests that:

The substance that knows itself as free, in which absolute ought is just as much being, is real as the spirit of a people. The abstract disruption of this spirit is its separation in persons, however, the spirit is the inner power and necessity of that independence. The person, as thinking intelligence, knows that substance as their essence, and ceases in this conviction to be an accident of it [...] The person does their duty, without selective reflection, as their duty and as something that is and has in this necessity their self and their real freedom. (GW 20: § 514) ${ }^{7}$

Hegel suggests that "real" freedom is constituted by our commitments to "real" and "necessary" "oughts." A person that understands that they are free in this sense knows that their freedom as "the spirit of a people" is a duty to "real" and "necessary" norms and to the normative realm of "being" in general. Furthermore, if we read this paragraph through the Brandomian lens of normative statuses, these "oughts" are fundamentally social statuses. Mirroring Brandom's case-law analogy, we are able to make judgments only by binding ourselves, collectively and individually, to the norms implicit in discursive practices. Part of our "essence" involves taking responsibility for discursive norms (in the sense of integrating our judgments within a reason-giving context of past, present and future commitments of others) and committing ourselves to being bound by such norms.

In light of Brandom's projection of normative pragmatics onto the mirror of history, Brandom's Hegel is thoroughly post-Kantian. Brandom's Hegel respects Kant's critique of transcendental arguments and metaphysical excursions. Moreover, Brandom's Hegel focuses on the normative statuses of commitment, responsibility and authority and the idea that freedom is necessarily self-legislated. If Brandom's Hegel appears to be criticising Kant, then the critique is centred not on Kant's use of the concepts of pure understanding, but on the "autonomy model" for the bindingness of normative statuses and conceptual content. Because the content of a judgment must have an authority that is independent of the responsibility that the judge takes for it, Brandom's Hegel's conception of normative statuses as social statuses attempts to solve the aporia that results when Brandom's Kant tries to maintain the relative independence of normative attitude and normative content according to an autonomy model that only allows for the individual attitudes of those who are judging. The issue is that it is not enough for me to endorse norms in the sense of allowing them to exercise an authority over me; my acknowledgment of certain norms is also a commitment in the eyes of others to attitudeindependent normative content that will "outrun" my current understanding. Therefore, 
even though we endorse a certain commitment when making a judgment, the content of that commitment is not entirely attitude-dependent. The institution of normative content demands a particular structure and a particular process that involves one's self and those others who determine the normative content that one is unable to grasp on one's own. For Brandom, Hegel's articulation of "real" freedom is characteristic of the structure and process of deontic scorekeeping, that is, the structure and process involved in mutually and dynamically holding discursive practitioners to account in the sociallysituated, implicit game of commitment-making, a game that is made explicit in the giving and asking for reasons. Furthermore, if these "real" and "necessary" "oughts" qua normative statuses are social statuses, then, according to Brandom, mutually and dynamically holding one another to account involves "socially perspectival normative attitudes of attributing and undertaking such commitments" (Brandom, 1994: 62). ${ }^{8}$

For Brandom, the move from Kant's autonomy model to Hegel's social model takes place when the notions of commitment, responsibility and authority are incorporated within a symmetrical structure and dynamic process of reciprocal recognition. It is not enough that I merely undertake responsibilities and acknowledge others as having authority over me; others must hold me responsible and exercise authority over what I am committed to, responsible for and authoritative about. Furthermore, because social statuses are instituted through normative, practical attitudes that, according to Brandom, necessarily involve a multiplicity of social perspectives, and because others are holding me responsible for what I am committed to, I must also hold myself responsible. As a scorekeeper with a certain social perspective, it is my "duty" to assess, challenge and revise my own commitments just as it is my duty and the duty of all scorekeepers to assess, challenge and revise the commitments of other scorekeepers and the commitments that "outrun" those that are explicitly acknowledged. The key issue for Brandom and Brandom's Hegel is that the structure and process that constitute a being capable of judgment are social and reciprocal. ${ }^{9}$ Simultaneously, the same structure and process of reciprocal recognition synthesizes a normative community of those recognised by and who, in turn, recognise a norm-responsive individual. In other words, the application of concepts and the institution of genuine normative statuses are based on a social process of reciprocal recognition on the part of those becoming responsible and those holding others responsible, a process that, simultaneously, synthesizes a community capable of judgment - a community that Brandom's Hegel calls Geist.

Just as case-law judges rationally integrate a legal concept via a process of rational recollection, thereby giving rise to a temporally perspectival structure for the determination of legal concepts, the structure of reciprocal recognition that institutes normative statuses also includes a dynamic, temporal aspect. According to Brandom, Hegel presents a retrospective notion of rationally reconstructing the process that led to the commitments currently being integrated. This is "a genealogical justification or vindication of those commitments, showing why previous judgments were correct in the light of still earlier ones - and in a different sense, also in the light of subsequent ones" (Brandom, 2009: 90). According to Brandom's Hegel, the structure of reciprocal recognition takes the form of a "historical-developmental process" whereby the institution of normative statuses, conceptual contents and facts takes place by considering - mutually and symmetrically - "prospective and retrospective temporal recognitive perspectives" (ibid.: 93). In other words, when the structure of reciprocal recognition takes the special form of a developmental process through history, what is 
presented is a historically-aware social community for whom conceptual contents and discursive commitments can become elevated to the status of facts. According to Brandom, what Hegel presents is a "phenomenology" insofar as "he starts with an account of phenomena (what things are for consciousness) and seeks to reconstruct the notion of noumena (what things are in themselves) out of the resources it provides" (ibid: 99-100). Specifically, Hegel's "idea of noumena, of things as they are in themselves, the reality that appears in the form of phenomena, can be understood practically in terms of a distinctive role in a recollectively rationally reconstructed historical sequence of phenomena" (ibid $\therefore$ 99; italics added).

The issue is that the reciprocal recognitive relationship is not just a social phenomenon. The "phenomenal" interpretation of the relation of reciprocity is justified by Hegel on the basis of his speculative logic (and its aims for systematic completion and unity). It is this logical element that invites an engagement with the ethical dimension of Hegel's practical philosophy, a dimension that remains unaccounted for in Brandom's Hegel and that has not been incorporated within Brandom's model of normative pragmatics and inferential semantics. One might argue, of course, that because Brandom's philosophical historiography involves "selection, supplementation and approximation" (Brandom, 2002: 111), he need only draw upon those ideas and solutions congenial for his own enterprise. If Brandom can adequately explain the sense of content bearers in terms of normative pragmatics and inferential semantics, then why should he concern himself with more substantive speculative and ethical matters? Firstly, it is not clear that Hegel's systematic approach warrants a more piecemeal reading and application. ${ }^{10}$ Secondly, putting aside questions of textual fidelity, Brandom's framework faces two entwined challenges when considered in the light of real discursive practices:

a) the problem of social positivism;

b) the lack of a reasonable explanation for the distinction between legitimate and illegitimate norms.

In order to understand not only how these two Hegelian problems arise for Brandom (and Brandom's Hegel), but how Hegel deals with them, one needs to understand the implications of the latter's speculative logic for Brandom's Hegel (and, by extension, for Brandom's framework).

As we have seen, based on a "Whiggish," temporally perspectival model, it is the idea that the noumenal - how things really are - emerges from out of the phenomenal - the realm of the social - which Brandom sees as being articulated in the work of Hegel. However, the key issue for Hegel is the truth that the relata of judgment and judged, of practical attitude and normative status, of norms and facts, are constituted and connected by a more fundamental "truth," one that lies between the relata as "the third to being and essence, to the immediate and to reflection" (GW 12: \$11). What makes Hegel's position more substantive is the fact that his criticisms of representationalism, finite cognition based on the categories of traditional logic and the doctrine of isolable and independent things-inthemselves can only be justified by articulating an "absolute foundation" and "truth" (GW 12: §11). Ultimately, for Hegel, this "third" will take the form of the "Concept"; "the totality resulting from the relation of reciprocity" (ibid.: §15; italics added). The upshot of this "truth," as Stephen Houlgate observes (2007: 149), is that empirical conceptual norms may be socially instituted, but fundamental categories like Hegel's "Concept" are necessary by virtue of the dialectical character of thought, a character that cannot be transcendently or socially explained. 

Hegel's position on the negation of the independent being of everything other than the self-conscious "I" can only be explained by appealing to the "absolute foundation" that operates as the truth in his framework. He explains that the notion of an independent fact, object or property, which both mind and language somehow represent, lacks any "beingfor-itself." It lacks an "essential character" that "distinguishes it from all others" in such a way that it is "in opposition to other things" (PG: §125). ${ }^{11}$ For Hegel, "being and essence no longer have determination as being and essence, nor are they only in such a unity in which each would mirror the other" (GW 12: \$29). At best, the idea that both mind and language mirror an independent reality is merely derivative as a modification of consciousness. As Brady Bowman observes, the key point of this particular approach to idealism is that, as an articulation of the dialectical character of thought, it cannot achieve an expression of reality in accordance with anything like being-for-itself. In short, there is no "stable, objective expression" of dialectical thinking with which mind and language can correspond (Bowman, 2013: 137). ${ }^{12}$ Rather, Hegel argues that what is established is an object's "continuity with others, and for it to be connected with others is to cease to exist on its own account" (PG: \$125). He goes on to claim that:

It is just through the absolute character of the thing and its opposition to others that it relates itself to others, and it is essentially only this relating. The relation, however, is the negation of the thing's independence, and it is thus really the essential property of the thing that is its undoing. (Ibid.)

In short, the notion of an independent object, which both mind and language represent, is undermined by that object's "essential property"; its relationship with other objects. It is this essential necessary relationship that, for Hegel, calls into question the traditional metaphysical conception of "being-for-itself."

Translating Hegel's rejection of a mind-independent reality into Brandom's terms, "how things really are, objectively, in themselves" is essentially mediated by its relation to integrating and recollecting consciousness, which is itself mediated by its relation to the reality related to acts of judgment. Therefore, both judgment and what is being judged are relational through and through such that reality - that which is rationally integrated through rational recollection - is "essentially only this relating." In other words, two relata (judgment and judged) are essentially involved such that judgment is a relation and that which is judged is also a relation. Furthermore, not only is the judgment-relation related to what is judged, that which is judged is related to judgment in order to relate to itself and thereby constitute the self-relation it essentially is. Accordingly, judgment is, simultaneously, a complex structure and process whose elements are defined in purely relational terms such that the whole structure-cum-process is itself a relation, which Hegel calls the "Concept." Following his critique of the notion of "being-for-itself," Hegel argues that "the Concept does not differentiate itself into determinations" (GW 12: \$29). Rather, the Concept is "the truth of the substantial relation" - the relation of reciprocity whereby "being and essence individually attain their perfect independence and determination through the other" (ibid.). ${ }^{13}$

The upshot of this aspect of Hegel's speculative logic is that the content of the "truth" of concepts, that is, the "relation of reciprocity," cannot be normatively determined - it is necessary. For Hegel, we need some sort of guarantee that the basic structure of our social norms has been instituted in ways consistent with such a "truth." Broadly speaking, it is the manifestation of the "relation of reciprocity" at the social level that 
offers such a guarantee. Consequently, although the contents of judgment may be socially-achieved, partial and progressive normative facts, the institution of "real" or genuine normative statuses, the determination of "real" or genuine normative content and the assumption of a "task-responsibility" on the part of those engaged in judgment presupposes the actualisation of a historical-developmental process of mutual relating between deontic scorekeepers, a dynamic process that Hegel calls "becoming" (GW 12: §33). In other words, the "relation of reciprocity" not only provides a necessary structure for particular acts of judgment, it is also a necessary condition of a dynamic process that brings about the institution of "real" and "necessary" normative statuses and the determination of "real" and "necessary" conceptual contents.

Brandom is prepared to subscribe to the idea that a necessary condition of the institution of normative statuses is the actualisation of reciprocal, practical attitudes between deontic scorekeepers. ${ }^{14}$ However, unlike Hegel, he does not grant the relation of reciprocity an ethical reading. For Brandom, it is enough for his general account of normativity (and his rational reconstruction of the history of philosophy along those lines) that he provides a sufficient view of sociality. On that basis, the structure and process of reciprocal recognition, which, according to Brandom, involves socially perspectival normative attitudes of attributing and undertaking commitments, is merely what is needed to account for sociality and to cross the boundary between the natural and the normative. ${ }^{15}$ For Hegel, however, sociality cannot be considered separately from ethics, specifically, "ethical life" (Sittlichkeit). In Hegel's account, the relation of reciprocity functions as a condition for the possibility of freedom. Hegel conceives freedom not as a property, a causal capacity nor as a matter of responding to contingent desires or external pressures, but as a collective achievement of a "state" of mutual relating between social beings. ${ }^{16}$ This state should not be interpreted as a relation of utility, mutual necessity or in terms of a legal notion of mutuality of recognition. Furthermore, the relation of reciprocity should not just be conceived in terms of equal status between morally responsible subjects in the sense of mutual welfare respect or respect of moral intentionality. For Hegel, the state of freedom is necessary for social beings to engage each other on a genuine normative basis. In his reading of Kant, Brandom (2009: 58) acknowledges the fact that "positive freedom," as a "freedom to do something, rather than freedom from some sort of constraint," is expressed by a subject's normative ability to make commitments, to become responsible and to bind itself to conceptual norms. For Hegel, however, the key issue is that such an expression of positive freedom true self-determination - requires the achievement of a state of concrete normative interactive equality. As Pippin (2008: 198) observes, "being a free rational agent consists in being recognised as one, and one can only be so recognised if the other's recognition is freely given; and this effectively means only if I recognise the other as a free individual, as someone to be addressed in normative not strategic terms." In other words, true sociality of competent concept appliers presupposes a state of freedom consisting of reciprocal relations between normative social beings. For Hegel, the relation of reciprocity is ethical (and not just a condition of sociality) because without the manifestation of such a relation a subject is unable to engage genuinely in the normative game of giving as asking for reasons and, on that basis, a subject cannot genuinely selfdetermine or genuinely be who he or she is.

According to Hegel, by responding to normative statuses and normative contents in acts of judgments and the game of giving and asking for reasons, we do not deliberate as 
rational agents but as "ethical beings" (sittliches Wesen) in a form of "ethical life" (Sittlichkeit) of recognitive relationships. ${ }^{17}$ For Hegel, both the game of giving and asking for reasons and our genuine commitments and responsibilities to the "real" and "necessary" "oughts" of that game presuppose the conditions of ethical intersubjective relating that is reciprocal through and through. The recognitive relationship cannot be coerced. Moreover, from a Hegelian perspective, judges and scorekeepers cannot be indifferent to this ethical dimension without calling into question the justifiability of their practical attitudes and their contribution to the determination of normative statuses, and without losing their hold on their judgments as genuine, justifiable or legitimate normative claims about the way the world is.

Hegel attempts to make some sort of systematic sense of the distinction between those concrete social structures and processes that institute legitimate social norms and those that bring about unjustifiable social norms. It is because he provides the means to ground this distinction in his theory of freedom, specifically, in the collective achievement of a state of reciprocal recognitive relationships, that an explanation can be offered for the differences between behaviour resulting from coercion and genuine norm-responsive behaviour. However, Brandom does not consider the implications of Hegel's ethical dimension of sociality. As we shall see, this is one way of explaining the first issue with Brandom's framework, namely:

Commentators suggest that he is committed to a kind of social positivism that forces deontic scorekeepers to merely accept social practices as immune to criticism. ${ }^{18}$

Whereas Hegel can be interpreted as making a distinction between legitimate social norms derived from reciprocal recognitive relationships between "ethical beings" and illegitimate norms that emerge out of non-recognitive relationships of domination, Brandom is unable to sufficiently explain the distinctions between legitimate and unjustifiable norms and between practical attitudes and normative statuses. Such an explanation is lacking in Brandom's account because he overlooks the distinction between coerced behaviour and genuine norm-responsive behaviour that is a key aspect of Hegel's account of social practice as a "struggle for recognition," a struggle that can only be resolved by reciprocal recognitive relationships constitutive of an achieved collective state of freedom. This leads to the second issue with Brandom's framework:

Without a reasonable explanation for the distinction between justifiable and unjustifiable social norms, Brandom's model is unable to explain why, rather than establishing a Sittlichkeit of successful mutual recognition and normative equality that justifies the conflation of norms and facts, social recognition, in many cases, appears to facilitate attitudes that conform to unjust normative practices. ${ }^{19}$

From a Hegelian perspective, these two issues arise for Brandom because "Making It Explicit is officially silent on this topic [of ethical commitments]. The words 'morality' and 'ethics' (like 'experience') do not so much as occur in this long book" (Brandom, 2000b: 371). There appears to be two reasons for such silence. Firstly, as already mentioned, in order to offer a general account of normativity, Brandom believes that it is sufficient to explain sociality in terms of mutually and dynamically holding one another to account through "socially perspectival normative attitudes of attributing and undertaking such commitments." On that basis, as already demonstrated, Brandom's framework and his appropriation of Hegel for the demands of that framework presuppose the ideal conditions of reciprocal recognitive attitudes between deontic scorekeepers. Secondly, according to Brandom, the omission of ethical considerations is required in order that 
"some ground might be gained by addressing discursive norms undistracted by the special features historically treated as distinctive of moral ones" (ibid.). According to Brandom, we cannot have contentful moral attitudes (and contentful moral intentions for action) before we have a discursive practice and the norms implicit in that practice. As we have seen, content is conferred upon a concept by the commitments a judgment both acknowledges and expresses. These commitments are part of a normative practice that involve inferential relationships. Prior to this practice, all we encounter, according to Brandom, are various perceptual behavioural dispositions. Consequently, from Brandom's perspective, in order to have moral content, we require a certain amount of conceptual content in general as well as discursive norms. We also require that the normative social practice is already underway. Such an interpretive issue may seem to rule out the Hegelian possibility that genuine normative sociality presupposes normative equality in the recognitive interactions between social beings. However, there are reasons for thinking that this is not the case and that the challenges facing Brandom's account are, from a Hegelian point of view, genuine problems.

Firstly, and perhaps most importantly, the concept of the "ethical" is to be interpreted in the light of Hegel's theory of freedom. According to this theory, in order to be a rational, normative and norm-responsive subject, who is able to institute genuine normative statuses and partake genuinely in the normative game of giving and asking for reasons, that subject must be free. In order to be free, that subject must be recognised as a rational, normative and norm-responsive subject, who is able to institute genuine normative statuses and partake genuinely in the normative game of giving and asking for reasons. Furthermore, that recognition must be freely given in the sense that those doing the recognising are recognised in the same way. In other words, there must be an achievement of some collective state of freedom consisting of a structure-cum-process of mutuality of recognition indicative of normative equality. On this reading, the ethical dimension of Hegel's practical philosophy should not be interpreted in some propertybased, matter-of-fact or metaphysical sense that precedes discursive practice and the norms implicit in that practice. Furthermore, on the basis that freedom should be understood as a state of specifically normative equality, the ethics of mutual recognition cannot be interpreted solely in legal and moral terms. In other words, for the achievement of normative equality it is not enough that the recognitive relationship consist in mutual respect between morally-responsible, rights-bearing social beings. Indeed, in a certain sense, Hegel echoes Brandom's concerns about "distinctive" moral norms. The point is that without an "ethical life" (Sittlichkeit) in which social beings recognise, and are recognised as, rational, normative and norm-responsive subjects, the notion of contentful moral or legal attitudes will appear empty. ${ }^{20}$

Another reason for believing that Hegel's theory of freedom raises questions regarding Brandom's framework is that whereas Brandom aims to offer an account of the normativity of discursive practices based on the ideal conditions of reciprocal recognitive attitudes between deontic scorekeepers, Hegel sees the development of normative situations over time as being more relevant. Because Hegel is more concerned with the actualisation of normative authority at specific times, the continuous historical development of norms and, indeed, historical processes of normative change, the Brandomian problem of the origin of the ethical dimension of normative social practice is not as relevant as the systematic explanation of the distinction between justifiable and unjustifiable social norms. Under the ideal conditions of reciprocal recognition between 
deontic scorekeepers, such a distinction, for Hegel, is of little or no relevance. Consequently, there is little or no need to consider the ethical implications and dimensions of normative social practice. From Hegel's perspective, however, "ethical life" and discursive norms do not come apart. Furthermore, they cannot, in real discursive situations, be conflated in the name of an ideal discursive rationality. ${ }^{21}$ That the two are interrelated is an idea I will explore in the next section.

\section{The Justifiability of Norms}

In the previous section I argued that Brandom accepts reciprocal, practical attitudes between deontic scorekeepers as a necessary condition for the institution of normative statuses. However, when it comes to real judgments, it is precisely the legitimacy of socially-instituted norms of judgment that is under consideration. In concrete circumstances, genuine normative statuses, judgments and reasons arrived at through a rational ${ }^{22}$ process of integration and recollection can conflict with those norms derived from non-reciprocal recognitive relationships that undermine normative equality, for example, through coercion and manipulation or as a result of generic measurement, bureaucratic organisation, the social privileging of utilitarian attitudes and various reifying stereotypes (of race, class, gender, sex, disability, mental health, psychology, and so on). ${ }^{23}$

31 The key issue is that if we are to accept Brandom's explanation for the social determination of normative statuses, conceptual contents and facts as based on a model of reciprocal recognition, then, from a Hegelian perspective, questions concerning normative validity in real situations cannot be considered separately from the ethics of social recognition. This is a substantive point for Hegel, who, on one reading, suggests that the question of the content of judgment cannot be considered independently from the question of the authority of judgment, that is, independently from the question of whether a judgment is justifiable. ${ }^{24}$

As we have seen, Brandom is also concerned with the question of normative authority. By making the distinction between commitments and entitlements, he gestures at the dialectical interplay between responsibility and authority in the context of judgment. In a normative discursive context, however, Brandom's notion of authority is solely concerned with the practice of binding one's self to commitments and conceptual contents. For those that accuse Brandom of committing to social positivism, his notion of authority lacks an additional dimension that explains how discursive participants can justifiably call into question claims to normative authority. The reason why Brandom's framework can explain how authority licenses someone to bind themselves to conceptual norms but not how a person can challenge normative authority is because, as we have seen, Brandom's model for the institution of normative statuses assumes the ideal conditions of sociality. In order to justifiably criticise social norms, we need a gap to appear between legitimate social norms and unjustifiable social norms. At the structural level, if we assume that the ideal conditions of reciprocal recognition hold, the distinction between legitimate and illegitimate norms will be explanatorily empty. For Hegel, we can only make sense of such a distinction by appealing to the differences between genuine responses to normative authority and those responses that, even if they involve commitments, acknowledgements and attitudinal endorsements in the game of giving and asking for reasons, arise from coercive or manipulative discursive environments. As 
we have seen, Hegel is able to offer a broader account of normative authority, one that attempts to overcome the problem of social positivism, by making systematic sense of the distinction between coerced and genuine self-determining, norm-responsive behavior on the basis of his theory of freedom. For Hegel, we cannot assume that in every appeal to normative authority the ideal state of reciprocal recognition has been achieved. In order to understand the ways in which the content of a judgment is bound up with its authority, we need to see not only how that relationship manifests in real circumstances, but how those circumstances relate to a state of concrete normative interactive equality.

From a Hegelian perspective, what makes non-recognitive relationships qua practices of domination a very powerful and a very real enemy of Brandom's normative pragmatics is their ability to undermine the validity of normative statuses and conceptual contents in specific situations and at certain times. Furthermore, non-recognitive social practices can also call into question Brandom's conception of positive freedom as self-legislation, which forms the basis of his account of the institution of normative statuses and the social determination of conceptual contents. For example, domination can be said to operate by subjecting individuals to unjust normative forces beyond their control, which those individuals, nevertheless, institute by undertaking commitments in the name of recognition and in order to play the game of giving and asking for reasons. Due to the fact that commitments, responsibilities and authorities that result from violations of the principle of reciprocal recognition can still be acknowledged as normative statuses over time such that they seemingly legitimatise the non-reciprocal ways in which subjects deal with each other within various social relationships, a Hegelian approach considers whether normative statuses, conceptual contents and facts actually disguise nonreciprocal processes and structures of recognition.

If Brandom's pragmatic inferentialism assumes a one-dimensional account of normative authority on the basis of ideal conditions of sociality, then, in order to adapt it for the real conditions of everyday discursive practices, Hegel's distinction between unjustifiable and justifiable appeals to normative validity needs to be accounted for within Brandom's model. To argue, as Fossen (2011) does, that real discursive practice is "contestatory" is to misunderstand or overlook Hegel's substantive point that the content of judgment cannot be considered independently from the question of the authority of the judgment. Even if it is the case that there is an essential and underappreciated "agonal" dimension to Brandom's conception of discursive practice, ${ }^{25}$ one that allows him "to avoid the pitfalls of subjectivism and communal assessment" and to avoid "collapsing the distinction between normative statuses and practical attitudes at the individual or communal level" (Fossen, 2011: 385-6), such a dimension (on its own) cannot provide an account of how one might go about adjudicating on the justifiability of something that is taken to be normatively valid. ${ }^{26}$ As has already been mentioned, for Hegel, to adjudicate on the justifiability of claims to normative authority, we need to draw upon the distinction between genuine appeals to normative authority and unjustifiable appeals. On the basis that Hegel grounds such a distinction in his theory of freedom, it is only when we understand that "ethical life" discourse is essentially "agonal" that we can begin to make sense of real distinction between legitimate and illegitimate discursive norms. "Ethical life" discourse does not assume that the reciprocal recognitive relationships constitutive of an achieved collective state of freedom hold. Rather, "ethical life" discourse occurs in a practical context of a "struggle for recognition." 

validity and presupposes ideal conditions of reciprocal recognition, the task of accommodating the distinction between legitimate and unjustifiable appeals to normative validity within his framework is both a critical and controversial undertaking. It goes against the notion of a unity of reason that is at the core of Brandom's normative pragmatics and inferential semantics. ${ }^{27}$ By making such a distinction, we understand that it is possible that what is taken to be normatively valid may have emerged from - in Hegel's sense - ethically invalid social environments of non-reciprocal recognition. On that basis, we might revise Brandom's claims and suggest that a unity of reason under ideal conditions presupposes the relative autonomy of empirical, normative and ethical validity. However, were we to argue for the autonomy of ethical, normative and empirical validity, Brandom could not be expected to provide a deflationary metaphysics on the basis of scorekeeping attitudes of attributing and acknowledging normative statuses and the social determination of conceptual contents. In order to sacrifice the regulative assumption of an integration of different spheres of validity under ideal conditions so as to account for Hegel's distinction between unjustifiable and justifiable appeals to normative validity, the remaining option is to argue that although each sphere of validity (empirical, normative, and ethical) is attendant upon certain features specific to it, these features are interrelated with those that have been attributed to other types of validity. In other words, the seemingly autonomous or conflated spheres of validity are reciprocally related to the degree that concrete moves within one sphere (for example, moves that undermine an ideal collective state of normative equality qua reciprocal recognition) can affect the content of what is taken to be normatively valid. This is the substantive point that, as we have seen, Hegel appears to be committed to, namely, that the content of discursive expressions cannot be considered separately from the question of the authority of those expressions that have been acknowledged in specific ways at specific times.

Bearing in mind that, for Hegel, genuine (as opposed to coerced) responses to normative statuses and normative contents require that discursive practitioners deliberate as "ethical beings" in a form of "ethical life" of recognitive relationships, a Hegelian solution demands that practitioners make specific moves within the sphere of "ethical life" in order to achieve a collective state of reciprocal recognition qua normative equality that is necessary for genuine normative self-determination and thereby for the institution of genuine normative statuses and conceptual contents. Furthermore, unless we are to make the mistake of conflating normative and ethical validity, there must be something about the "ethical life" sphere of validity that is not currently provided by Brandom's account of how norms and facts emerge from social practices. ${ }^{28}$

In the spirit of Hegel's concept of "struggle for recognition," what sets a claim to normative validity in "ethical life" apart from a claim to normative validity in a positivist context is its inherently contestatory character. "Ethical life" arguments can be viewed as concerned almost exclusively with the articulation of specific situations, which are attendant upon actions and needs, as well as with the way that those who act or suffer normative consequences of actions see themselves. As Albrecht Wellmer has observed, the arguments and judgments that take place in a Hegelian context of "ethical life" are fallible because the validity of such discourse is often a matter of whether "my understanding of situations, the way I see myself, my interpretations, are appropriate, accurate or truthful" (Wellmer, 1986: 125). In other words, with "ethical life" arguments and judgments, one confronts one's self and, simultaneously, evaluates the features of the

European Journal of Pragmatism and American Philosophy, X-2 | 2018 
situation one finds one's self in. Therefore, the issue is not only whether a social norm, in real situations, is taken by scorekeepers to be justifiable, but also whether the judgmentmaker interprets it as being justifiable in the context of their specific experiences at specific times. In Brandom's terms, it is the "subjective" nature of de dicto interpretations (as opposed to the "objective" character of de re interpretations) that allow for this fallibilistic character of "ethical life" judgments (although, if we adopt an evaluative or hermeneutic model, what is "subjective" and what is "objective" cannot be distinguished in real dialogical situations of moral deliberation in the ways in which Brandom attempts to). ${ }^{29}$ Utilising Brandom's terms (but not his ideas), claims to normative validity in "ethical life" are special because they are initially concerned with what the individual takes to follow and what she takes to be incompatible as opposed to the commitments she actually undertakes according to those who acknowledge and recognise the individual's commitments. In other words, de dicto interpretations of real situations in "ethical life" are "what the author took it that she was committing herself to by making a certain claim, what she would have regarded as evidence for it or against it [...] So [the claim] tells us something about how she understood what she was claiming" (Brandom, 2002: 96). On this basis, an evaluative stance not only opens up the possibility that we may have something to learn from social norms, it demands that our concrete experiences at specific times can call into question and bring about a revision of those norms as result of our specific interpretations that express those experiences.

In many cases, interpretations that express specific experiences will make use of justifiable exceptions to social norms. Taking moral discursive norms as an example, if we imagine a situation in which moral norms have emerged from contexts of domination, then challenging such norms will require moral arguments derived from specific experiences at specific times that bring exceptions into play, exceptions that cannot be made to conform to these norms. From a Hegelian perspective, these exceptions will be normatively legitimate or justifiable if they promote conditions of mutual recognition necessary for genuine normative self-determination and normative equality. The key point is that claims to validity in "ethical life" are not entirely norm-bound. The legitimacy of norms in "ethical life" only stretches as far as the legitimacy of the recognitive relationships that exist between discursive practitioners. As a result, "ethical life" norms carry a situational index that binds them to the specific situations in which they have their origins..$^{30}$ What makes claims to normative validity in "ethical life" so important in terms of the present discussions regarding the need for, rather than the presence of, an achieved collective state of normative equality as the basis for the institution of genuine normative statuses and conceptual contents, is that it allows for the questioning and transcendence of what is considered to be normatively valid as a result of the exceptions that are brought into play in specific situations of judgment.

Without the actualisation of reciprocal recognition that grounds the legitimacy of genuine normative statuses, conceptual contents and facts, what Hegel calls "the march of reason" is less an unbroken, "Whiggish" progress towards truth and correct representation of reality, but more a question of extending relationships of mutual recognition qua normative equality through the critical undermining of socially inherited attitudes and illegitimate social norms. This (all-too-brief) account of normative validity in the context of "ethical life" is, from a Hegelian perspective, vital for dealing with the spectre of positivism that threatens Brandom's framework. Indeed, if the speculative logic of Hegel's Concept is the "truth" he claims it to be, the more we actualise and 
promote reciprocal recognition within an "ethical life," the more that form of life emerges as a rational culture.

\section{Conclusion}

In this paper, I have attempted to demonstrate that Brandom's normative pragmatics and inferential semantics presupposes the ideal conditions of sociality qua reciprocal recognition. Although Brandom admits to not having addressed the ethical issues that are entwined with his reading and appropriation of Hegel, we have seen that one way to deal with some of the issues concerning Brandom's framework is to argue that discursive rationality cannot be isolated from a form of mutually-recognising "ethical life." Consequently, from a Hegelian perspective, I argued that, in real situations, questions concerning normative validity must be understood in the context of our actual practices involving social recognition, which may or may not be justifiable according to the model of genuine mutuality qua normative equality. Rather than conflating normative and ethical validity in the name of an ideal practical reason, were we to acknowledge that what is normatively valid may conflict with what we understand to be (in Hegel's sense) ethically valid, the task presented to us by the evaluative-cum-situational nature of claims to normative validity in "ethical life" would be to use our specific experiences that bring exceptions into play in order to question and (potentially) transcend what we consider to be normatively valid with the view to instigating and spreading relationships of reciprocal recognition.

\section{BIBLIOGRAPHY}

Bowman Brady, (2013), Hegel and the Metaphysics of Absolute Negativity, Cambridge, Cambridge University Press.

BRANDOM Robert, (1994), Making it Explicit, Cambridge, MA and London, Harvard University Press. BRANDOM Robert, (2000a), Articulating Reasons: An Introduction to Inferentialism, Cambridge, MA and London, Harvard University Press.

BRANDOM Robert, (2000b), "Facts, Norms and Normative Facts: A Reply to Habermas," European Journal of Philosophy, 8 (3), 356-74.

BRANDOM Robert, (2002), Tales of the Mighty Dead: Historical Essays in the Metaphysics of Intentionality, Cambridge, MA and London, Harvard University Press.

BRANDOM Robert, (2009), Reason in Philosophy: Animating Ideas, Cambridge, MA and London, The Belknap Press of Harvard University Press.

DOSTAL Robert, (2011), “In Gadamer's Neighbourhood," in Jeff Malpas (ed.), Dialogues with Davidson: Acting, Interpreting, Understanding, Cambridge, MA and London, The MIT Press, 167-90. 
FOSSEN Thomas, (2011), “Politicizing Brandom's Pragmatism: Normativity and the Agonal Character of Social Practice," European Journal of Philosophy, 22 (3), 371-95.

GADAMER Hans-Georg, (1985-95), Gesammelte Werke, 10 vols., Tübingen, Mohr Siebeck.

HEGEL Georg Wilhelm Friedrich, (1968-), Gesammelte Werke, ed. by Nordrhein-Westfälischen Akademie der Wissenschaften, Hamburg, Meiner.

HEGEL Georg Wilhelm Friedrich, (1986), Phanomenologie des Geistes, vol. 3, Gesamte Werkausgabe, Frankfurt am Main, Suhrkamp.

HENRICH Dieter, (1978), “Hegels Logik der Reflexion (neue Fassung)," Hegel-Studien, 18, 204-324.

HONNETH Axel, (2009a), "Recognition as Ideology," in Bert van den Brink \& David Owen (eds.), Recognition and Power: Axel Honneth and the Tradition of Critical Social Theory, Cambridge, Cambridge University Press, 323-47.

HONNETH Axel, (2009b), Pathologies of Reason: On the Legacy of Critical Theory, transl. by James Ingram et al., New York, Columbia University Press.

HORSTMANN Rolf, (1984), Ontologie und Relationen: Hegel, Bradley, Russell und die Kontroverse über interne und externe Beziehungen, Königstein im Tannus, Athenäum.

HOULGATE Stephen, (2007), "Hegel and Brandom on Norms, Concepts and Logical Categories," in Espen Hammer (ed.), German Idealism: Contemporary Perspectives, London and New York, Routledge, 137-52.

LAFONT Cristina, (2008), "Meaning and Interpretation: Can Brandomian Scorekeepers be Gadamerian Hermeneuts?," Philosophy Compass, 3 (1), 17-29.

LANCE Mark, (2008), "Placing in a Space of Norms: Neo-Sellarsian Philosophy in the Twenty-First Century," in Cheryl Misak (ed.), The Oxford Handbook of American Philosophy, Oxford, Oxford University Press, 403-29.

LOEFFLER Ronald, (2018), Brandom, Cambridge, Polity Press.

MCDOWELL John, (1999), “Comment on Robert Brandom's ‘Some Pragmatist Themes in Hegel's Idealism'," European Journal of Philosophy, 7 (2), 190-3.

MCDOWELL John, (2009), The Engaged Intellect: Philosophical Essays, Cambridge, MA and London, The MIT Press.

MISAK Cheryl, (1998), "Deflating Truth,” The Monist, 81 (3), 407-25.

MISAK Cheryl, (2007), "Pragmatism and Deflationism," in Cheryl Misak (ed.), New Pragmatists, Oxford, Oxford University Press, 68-90.

PINKARD Terry, (2007), "Was Pragmatism the Successor to Idealism?,” in Cheryl Misak (ed.), New Pragmatists, Oxford, Oxford University Press, 142-68.

PIPPIN Robert B., (2005), “Brandom's Hegel,” European Journal of Philosophy, 13 (3), 381-408.

PIPPIN Robert B., (2008), Hegel's Practical Philosophy: Rational Agency as Ethical Life, Cambridge, Cambridge University Press.

PRICE Huw, (2011), Naturalism Without Mirrors, Oxford, Oxford University Press.

PRICE Huw, (2013), Expressivism, Pragmatism and Representationalism, Cambridge, Cambridge University Press. 
PRIEN Bernd, (2010), "Robert Brandom on Communication, Reference, and Objectivity,"

International Journal of Philosophical Studies, 18 (3), 433-58.

PUTNAM Hilary, (1981), Reason, Truth and History, Cambridge, Cambridge University Press.

PUTNAm Hilary, (1985), Realism and Reason, vol. 3 of Philosophical Papers, Cambridge, Cambridge

University Press.

PUTNAM Hilary, (1988), Representation and Reality, Cambridge, MA, The MIT Press.

PUTNAm Hilary, (1992), Renewing Philosophy, Cambridge, MA and London, Harvard University

Press.

RAMBERg Bjørn, (2000), "Post-ontological Philosophy of Mind: Rorty versus Davidson," in Robert B. Brandom (ed.), Rorty and His Critics, Oxford, Blackwell, 351-69.

RAMBERG Bjørn, (2008), "Rorty, Davidson, and the Future of Metaphysics in America," in Cheryl Misak (ed.), The Oxford Handbook of American Philosophy, Oxford, Oxford University Press, 430-48.

REDDING Paul, (2007), Analytic Philosophy and the Return of Hegelian Thought, Cambridge, Cambridge University Press.

RORTY Richard, (1979), Philosophy and the Mirror of Nature, Princeton, NJ, Princeton University Press.

RORTY Richard, (1982), Consequences of Pragmatism, Cambridge, Cambridge University Press.

RORTY Richard, (1991), Objectivity, Relativism, and Truth, Cambridge, Cambridge University Press.

STOUT Jeffrey, (2007), "On Our Interest in Getting Things Right: Pragmatism without Narcissism," in Cheryl Misak (ed.), New Pragmatists, Oxford, Oxford University Press, 7-31.

VAN FRAASSEN Bas C., (1980), The Scientific Image, Oxford, Oxford University Press.

WEISS Bernard \& Jeremy WANDERER (eds.), (2010), Reading Brandom: On Making It Explicit, New York and London, Routledge.

WELLMER Albrecht, (1986), Ethik und Dialog: Elemente des moralischen Urteils bei Kant und in der Diskursethik, Frankfurt am Main, Suhrkamp.

WILLIAMS Meredith, (2000), "Wittgenstein and Davidson on the Sociality of Language," Journal for the Theory of Social Behaviour, 30 (3), 299-318.

WILLIAMS Meredith, (2010), Blind Obedience: Paradox and Learning in the Later Wittgenstein, New York and London, Routledge.

WiLliams Michael, (2010), “Pragmatism, Minimalism, Expressivism," International Journal of Philosophical Studies, 18 (3), 317-30.

\section{NOTES}

1. See, for example, Price 2011, 2013; Putnam 1981, 1985, and 1992; Ramberg 2000, 2008; Rorty (1979; 1982: 160-75; and 1991: 1-17, 113-61); Stout 2007; van Fraassen 1980.

2. See, for example, Lance 2008; McDowell 1999; Prien 2010; Redding (2007: 56-84); Weiss \& Wanderer (eds.) 2010; Williams, Michael 2010.

3. For a discussion of Brandom's approach to philosophical historiography, see Brandom (2002: 1-17). 
4. For discussions of some of the social and political implications of Brandom's framework, see Loeffler 2017, Fossen 2011, and Pippin 2005.

5. See Brandom (2009: 52-77).

6. Although, as Loeffler (2018: 201-29) demonstrates, Brandom's account of the objectivity of conceptual norms is structurally multisided, I have chosen to focus on the case-law analogy. According to Brandom, it is this dimension of his own account that is the most recognisably Hegelian. That said, I do touch on other aspects of Brandom's account, including semantic underdetermination (a key theme in Hegel) and the distinction between correct applications of concepts and applications that are merely taken to be correct (again, another central theme in Hegel). Such a focus is, I believe, sufficient to deal with the issues I wish to raise in this paper.

7. GW stands for Hegel's Gesammelte Werke. The section number (§) is given.

8. For a discussion of how the "I-thou" relationship (as a source of normativity) operates in the work of Donald Davidson, see Dostal 2011; McDowell (2009: 134-51). For a comparative study of the "I-thou" and "I-we" forms of sociality in Davidson and Wittgenstein, see Williams, Meredith 2000 and 2010.

9. As Brandom (2009: 70) claims, "Hegel's view is what you get if you take the attitudes of both recogniser and recognised, both those who are authoritative and those who are responsible, to be essential necessary conditions of the institution of genuine normative statuses, and require in addition that those attitudes be symmetric or reciprocal."

10. Pippin (2005: 400) has made the point that Hegel's position is "far more substantive, far less formal, than that attributed to him by Brandom."

11. PG stands for Hegel's Phänomenologie des Geistes. The section number (§) is given.

12. For a similar reading of Hegel's Concept, see Horstmann 1984.

13. Hegel's dictum, "The true is the whole" (GW 9: $\$ 20$ ), has been interpreted as suggesting that any particular truth is "untrue" when understood in the context of the whole. Thus, Hegel's speculative science aims for systematic completion. Brady Bowman (2013), combining respective analyses by Dieter Henrich (1978) and Rolf Horstmann (1984), argues that it is the dynamic nature of absolute negativity and the structural character of the Concept, which are one and the same, that make up Hegel's conception of systematic unity and totality.

14. See Brandom (2009: 70).

15. Mutual recognition plays a vital role in accounting for sociality in the work of Davidson and Wittgenstein. See the references in footnote 9.

16. See, for example, Pippin (2008: 183-209).

17. For a detailed account of ethical life theory as an account of successful recognition, see Pippin 2008.

18. See, for example, Pippin 2005 and Pinkard 2007. Pippin (2005: 392) claims that Brandom "does not yet explain how either an external interpreter or internal participant can properly challenge the authority of the norms on the basis of which the attributions and assessments are made, or how those norms can fail to meet those challenges." Pinkard accuses Brandom of aligning himself more with Fichte's position than that of Hegel. According to Pinkard, Fichte suggests that "what I ought to do is constrained by what the other actually, factually does" (Pinkard 2007: 166). Similarly, Brandom "reduces normativity to 'positive' socially enforced rules rather than holding fast, as Hegel does, the irreducible normativity (or what Hegel calls 'absolute negativity') of our practices" (ibid.).

19. A similar point is made by Axel Honneth (2009a: 323).

20. See, for example, Pippin (2008: 207).

21. Brandom acknowledges that "Habermas is right to detect sympathy for an assimilation of normativity in general to specifically conceptual normativity (as I think Kant and Hegel do)" (Brandom, 2000b: 371). 
22. For Hegel, the state of freedom constituted by reciprocal recognitive relationships is considered to be rational.

23. Honneth has also appropriated the distinction between justifiable and illegitimate norms on the basis of distortions of recognitive relationships in concrete social practices. Referring to the model of reciprocal recognition as both an "ideal" and a "rational universal" (Honneth 2009b: 25 ), he argues that deviations from the ideal are indicative of "forms of recognition that must be regarded as being false or unjustified because they do not have the function of promoting personal autonomy, but rather of engendering attitudes that conform to practices of domination" (Honneth, 2009a: 324-5).

24. See Pippin (2005: 393-4).

25. This question is still up for debate. See Pippin 2005; Pinkard 2007; and Fossen 2011.

26. In Making It Explicit, Brandom offers an account of the objectivity of conceptual norms as transcending contingent discursive situations. He famously asserts that "what is shared by all discursive perspectives is that there is a difference between what is objectively correct in the way of concept application and what is merely taken to be so" (Brandom, 1994: 600). On the basis of the objectivity of conceptual norms, it could be that a whole community is objectively wrong in the application of a concept. This means that such objectively incorrect agreements are, in principle, open to criticism and future revision. The point raised against Fossen's claim regarding the "agonal" dimension of Brandom's framework can also be applied to Brandom's account of the "wrong community." Specifically, without a way of grounding the distinction between illegitimate and legitimate conceptual norms, such a concession is explanatorily empty. One way to explain the distinction, as we have seen, is to make a distinction between genuine claims to normative authority and those claims that arise from coercive or manipulative discursive environments, and to ground that distinction in a theory of freedom according to which coercive discursive practices do not allow for genuine normative self-determination to the degree that discursive practitioners are unable to engage genuinely in the normative game of giving as asking for reasons. This is why Hegel, unlike Brandom, is so preoccupied with an account of social practice as a "struggle for recognition." Ultimately, the struggle can only be resolved by reciprocal recognitive relationships constitutive of an achieved collective state of freedom in ethical life.

27. In certain places, Brandom seems to subscribe to "metalevel nihilism about the moral," suggesting that there is nothing in particular that usually denominated "moral" reasons have in common that would justify grouping them together as moral reasons (Brandom, 2000b: 372).

28. This claim presupposes that we accept that Brandom is committed to a form of social positivism.

29. I am aware that I am not using the terms de re and de dicto in the ways interpreters of Brandom have suggested. After all, it is this demand for a distinction between what Brandom calls "subjective" and "objective" ascriptions that Cristina Lafont (2008) calls into question with the help of Hans-Georg Gadamer's hermeneutics (GW 1; GW 2). The reason for the comparison is to illustrate that whilst, for Brandom, pragmatic explanation of language and intentionality places greater importance on de re ascriptions in order to account for the representational dimension of propositional content, the special character of "ethical life" validity leaves space for the salvaging of situational, evaluative "subjectivity" in relation to social norms that is precisely not identical and not reconcilable with them.

30. See Wellmer (1986: 134). 


\section{ABSTRACTS}

In order to develop his pragmatist and inferentialist framework, Robert Brandom appropriates, reconstructs and revises key themes in German Idealism such as the self-legislation of norms, the social institution of concepts and facts, a norm-oriented account of being and the critique of representationalist accounts of meaning and truth. However, these themes have an essential ethical dimension, one that Brandom has not explicitly acknowledged. For Hegel, the determination of norms and facts and the institution of normative statuses take place in the context of Sittlichkeit ("ethical life"). By engaging with some of the more ontologically and ethically substantive points raised by Hegel, I argue that, from a Hegelian perspective, Brandom's project regarding the social determination of truth and meaning cannot be divorced from ethics, specifically, the ethical dimension of social recognition. Furthermore, I argue that, in real situations (as opposed to ideal ones), claims to normative authority cannot be considered independently from the legitimacy of those claims, a legitimacy that Brandom is unable to reasonably explain. Finally, I argue that a Hegelian solution to the problems facing Brandom's framework calls into question the unity of reason that is at the core of Brandom's normative pragmatics and inferential semantics.

\section{AUTHOR}

\section{JONATHAN LEWIS}

Dublin City University

Jonathan.lewis[at]dcu.ie 